\title{
The influence of food intake on portal blood flow and heat production in the digestive tract of sheep
}

\author{
By A. J. F. WEBSTER, P. O. OSUJI*, F. WHITE \\ AND J. F. INGRAM \\ Rowett Research Institute, Bucksburn, Aberdeen $A B 29 S B$ \\ (Received I November 1974-Accepted 1o fanuary 1975)
}

\begin{abstract}
I. Measurements were made of portal blood flow, heat production and oxygen consumption in the digestive tract of sheep either fasted or given the following diets: chopped, dried grass; pelleted, dried grass; chopped, dried lucerne; pelleted, dried lucerne; or a pelleted barley diet.

2. For sheep that had been fasted for $48 \mathrm{~h}$, portal blood flow was $\mathrm{I} \cdot 84 \mathrm{l} / \mathrm{min}$, total visceral heat production was $62.3 \mathrm{~kJ} / \mathrm{kg}$ body-weight ${ }^{0.75}$ per $24 \mathrm{~h}$ and aerobic heat production, estimated from oxygen consumption, was $62 \cdot 1 \mathrm{~kJ} / \mathrm{kg}$ body-weight $\mathrm{t}^{0.75}$ per $24 \mathrm{~h}$.

3. Portal blood flow was markedly influenced by food intake, increasing from $\mathrm{r} \cdot 8 \mathrm{l} / \mathrm{min}$ for starved sheep to 2.4 and $41 / \mathrm{min}$ for sheep fed at maintenance and $2.5 \times$ maintenance levels of intake respectively. Variations in the quality and physical form of the diets had no apparent effect on portal blood flow.

4. There was a curvilinear relationship between total heat production in the gut and metabolizable energy (ME) intake. The increase obtained for levels of intake below maintenance was greatest with lucerne diets, and least with pelleted, dried grass or pelleted barley diets. Above maintenance levels of intake the rate of increase in heat production, with all diets, was about $150 \mathrm{~kJ} / \mathrm{MJ}$ ME intake.

5. The heat of fermentation, estimated from the difference between total visceral metabolism and the aerobic metabolism of the tissues of the gut wall, was 76,60 and $22 \mathrm{~kJ} / \mathrm{MJ}$ digestible energy intake for the dried grass, lucerne and barley diets respectively.

6. The contribution of fermentation heat and the aerobic metabolism of the gut to the total heat increment of feeding in sheep was assessed. It was concluded that about half the heat increment must be derived from tissues outside the digestive tract.
\end{abstract}

The efficiency with which metabolizable energy (ME) can support maintenance and live-weight gain in the sheep depends on the increase in the heat production of the animal associated with successive increments in ME intake. Variations in this, the heat increment of feeding due to the diet, are quite small for levels of intake below maintenance, but are much greater when intake exceeds maintenance levels. Armstrong \& Blaxter $(1957 a, b)$ found that this was, in part, the result of differences in the efficiency (in terms of energy utilization) with which the volatile fatty acids (VFA) acetate, propionate and butyrate are used for lipogenesis. However, the results of more recent studies, reviewed by Annison \& Armstrong (1970) suggest that the effect of differences in the molar yield of VFA on heat increment may, in most practical circumstances, be quite small, and these workers concluded that 'alternate explanation(s) must be sought for the decline in the efficiency with which ME surplus to maintenance is used to promote live-weight gain as foods become more fibrous'.

Osuji, Gordon \& Webster (1975) have recently measured the contributions of

* Present address : Department of Livestock Science, The University of the West Indies, St Augustine, Trinidad, West Indies. 
I26 A. J. F. Webster, P. O. Osuji, F. White and J. F. Ingram 1975 the energy cost of eating and rumination to the heat increment of feeding for sheep offered grass diets of different physical form. The present experiment was designed to estimate the contribution of fermentation heat and the metabolism of the tissues of the digestive tract, using measurements of portal blood flow and the differences in temperature and oxygen content between arterial and portal venous blood. A preliminary account of some of this work has been published (Webster, Osuji, White \& Ingram, I974).

\section{EXPERIMENTAL}

Animals

Experiments were done using thirteen greyface or cross-bred adult wether sheep whose average weight was $65 \mathrm{~kg}(\mathrm{SD} 7 \cdot 0)$. When the animals had fully recovered consciousness after surgery for implantation of catheters and thermocouples, they were put in smooth-sided metabolism cages and given free access to food and water. The animals remained in these cages for the duration of experiments which ranged from 3 to 8 weeks for each individual. All the sheep had been used in metabolism trials for at least 2 years before these experiments and were thoroughly accustomed to restraint and handling.

\section{Measurement of blood flow and visceral metabolism}

Portal blood flow was measured by continuous thermal dilution (Webster \& White, 1973). Total heat production in the digestive tract $\left(H_{t}, \mathrm{~kJ} / \mathrm{h}\right)$ was estimated from equation $\mathbf{I}$ :

$$
H_{t}=0.225 F\left(T_{\text {porta }}-T_{\text {aorta }}\right),
$$

where $F$ is blood flow $(\mathrm{ml} / \mathrm{min})$; the constant $0.225\left(=0.9 \times 4.18 \times 60 \times \mathrm{ro}^{-3}\right)$ is a value which incorporates the specific heat of blood (0.9) expressed on a $\mathrm{J} / \mathrm{ml}$ basis. The temperature difference $\left(T_{\text {porta }}-T_{\text {aorta }}\right)$ was measured direct from the e.m.f. generated between a pair of thermocouples placed in the portal vein and in the dorsal aorta close to the origin of the anterior mesenteric artery. This e.m.f. was amplified using a Rikadenki Aro microvoltmeter (T.E.M. Sales Ltd, Crawley, Sussex) giving, for an input signal of $5 \circ \mu \mathrm{V}$, an output of $10 \mathrm{mV}$ and a pen deflection, on a potentiometric recorder, of $200 \mathrm{~mm}$.

Each estimate of $H_{t}$ was obtained from two measurements of $F$ made at an interval of $\mathrm{x}_{5} \mathrm{~min}$ and the average value for $T_{\text {porta }}-T_{\text {aorta }}$ over the intervening period.

The aerobic metabolic rate for the tissues of the digestive tract $\left(H_{g}, \mathrm{~kJ} / \mathrm{h}\right)$ was estimated using values for oxygen consumption using equation 2 :

$$
H_{g}=\mathbf{I} \cdot 22 F\left(C_{\text {aorta }}\left(\mathrm{O}_{2}\right)-C_{\text {porta }}\left(\mathrm{O}_{2}\right)\right) \text {, }
$$

where $F$ is portal blood flow $(1 / \mathrm{min})$. For the constant $\mathrm{I} \cdot 22\left(=20 \cdot 4 \times 60 \times 10^{-3}\right)$ it is assumed that the energy equivalent for $\mathrm{O}_{2}$ consumption is $20.4 \mathrm{~kJ} / \mathrm{l}$, a value which can only be approximate (Blaxter, 1962). Measurements of $\mathrm{O}_{2}$ content 
$\left(C\left(\mathrm{O}_{2}\right), \mathrm{ml} / \mathrm{l}\right)$ were made using a Van Slyke apparatus, for samples of portal and aortic blood which were collected and stored under liquid paraffin. $H_{g}$ was estimated again from the mean of the two measurements of $F$ made at an interval of $15 \mathrm{~min}$, and the concentration difference of $C\left(\mathrm{O}_{2}\right)$ for single samples of blood taken from the porta and the aorta before the first measurement of $F$.

\section{Surgical procedure}

The procedure for implanting catheters and thermocouples into the mesenteric circulation was essentially similar to that described by Webster \& White (1973) but with certain modifications. The catheter for infusing saline $(9 \mathrm{~g} \mathrm{NaCl} / 1)$ (to produce thermal dilution) was implanted into a branch of the anterior mesenteric vein, not into the right ruminal vein as described formerly, since we had noticed that this latter vein was particularly susceptible to phlebitis.

Problems of phlebitis and other tissue reactions around catheters in the portal circulation of sheep have been discussed elsewhere (Webster, 1974). Briefly, the tissue reaction is seldom severe enough to cause clinically detectable disease in the sheep, but sooner or later a fibrin flap forms around the catheter tips. This acts as an effective one-way valve which allows infusion but not withdrawal of blood. Several attempts were made to overcome this problem. Our most successful approach to date, used in the last six preparations, was to pierce six holes of about $0.6 \mathrm{~mm}$ diameter in the terminal $20 \mathrm{~mm}$ of a polyvinyl catheter $\left(\mathrm{NT}_{3}\right.$, i.d. $\mathrm{I} \cdot 4 \mathrm{~mm}$, Shore scale 95; Portex Ltd, Hythe, Kent), and then, holding the catheter in steam, stretch the tip until the terminal opening was itself reduced to about $0.6 \mathrm{~mm}$. This catheter was then cemented to the sealed catheter containing the thermocouple. After the cement was quite dry, the catheters were soaked in a dilute solution of detergent for at least $24 \mathrm{~h}$ to remove all traces of solvent.

After this treatment the tips of the catheters were very flexible, and a Seldinger guide wire ('Safeguide'; Becton-Dickinson, Wembley, Middx.) was inserted into the sampling catheter during implantation to assist it through the contours of the mesenteric vessels.

\section{Experiments}

Basal metabolism in the gut. Measurements were made of $F, H_{t}$ and $H_{g}$ for six sheep that had not received food for $48 \mathrm{~h}$. These measurements were made between I and 4 weeks after surgery. Measurements of $F, H_{t}$ and $H_{g}$ were made as described above, at intervals of $2 \mathrm{~h}$ in a period of $8 \mathrm{~h}$.

Responses to food intake. The sheep were offered the following diets: chopped, dried grass; pelleted, dried grass; chopped, or pelleted, dried lucerne; a pelleted diet consisting mainly of barley (about $800 \mathrm{~g} / \mathrm{kg}$ ). The nutritive values of the diets are shown in Table I. Losses of food energy as faeces, urine and methane were measured as part of the routine programme of food evaluation done by the Calorimetry Section of the Rowett Institute. Values used for the net availability of ME at levels of intake above and below maintenance, are those reported by Wainman, Blaxter \& Smith (1972) for dried grass, by Webster, Brockway \& Smith (1974) for barley, 
Table I. Nutritive value of diets given to sheep

\begin{tabular}{|c|c|c|c|c|c|}
\hline Diet $\ldots$ & Drie & rass & Dried & cerne & Barley§ \\
\hline Physical form of diet $\ldots$ & Chopped & Pelleted & Chopped & Pelleted & Pelleted \\
\hline $\begin{array}{c}\text { Gross energy } \\
\mathrm{kJ} / \mathrm{g} \mathrm{DM} \\
\mathrm{kcal} / \mathrm{g} \mathrm{DM}\end{array}$ & $\begin{array}{c}19 \cdot 4 \\
4 \cdot 64\end{array}$ & $\begin{array}{c}18 \cdot 2 \\
4 \cdot 35\end{array}$ & $\begin{array}{c}19 \cdot 4 \\
4 \cdot 64\end{array}$ & $\begin{array}{l}19 \cdot 2 \\
4 \cdot 58\end{array}$ & $\begin{array}{l}17 \cdot 9 \\
4 \cdot 28\end{array}$ \\
\hline Metabolizability of gross energy* & 0.62 & 0.54 & 0.58 & 0.55 & 0.63 \\
\hline $\begin{array}{l}\text { Net availability of metabolizable } \\
\text { Below maintenance levels of } \\
\text { intake } f\end{array}$ & 0.70 & 0.73 & 0.70 & 0.70 & 0.71 \\
\hline $\begin{array}{l}\text { Above maintenance levels of } \\
\text { intake } \neq\end{array}$ & 0.37 & 0.44 & 0.31 & 0.44 & 0.49 \\
\hline $\begin{array}{l}\text { Crude protein (nitrogen } \times 6.25) \\
(\mathrm{g} / \mathrm{kg} \mathrm{DM})\end{array}$ & r 70 & 108 & $28 \mathrm{I}$ & 267 & 188 \\
\hline Digestibility of crude protein & 0.71 & 0.45 & 0.758 & $0.7^{6}$ & 0.79 \\
\hline $\begin{array}{l}\text { DM, dry matter. } \\
\text { * Measured at about the } m \\
\dagger \text { From Wainman, Blaxter } \\
\ddagger \text { Maintenance level of inta } \\
\S \text { Diet contained about } 800\end{array}$ & $\begin{array}{l}\text { ce level } \\
(1972) \text { a } \\
\text { taken as } \\
y / \mathrm{kg} \text {. }\end{array}$ & $\begin{array}{l}\text { ntake. } \\
\text { Webster } \\
\text { kJ metab }\end{array}$ & ockway & $\begin{array}{l}\text { mith } \\
\mathrm{kg}^{0 \cdot 75}\end{array}$ & \\
\hline
\end{tabular}

and the values for lucerne, are the results of unpublished experiments of $F$. W. Wainman and J.S. Smith; the maintenance level of intake was taken as $400 \mathrm{~kJ} \mathrm{ME} /$ $\mathrm{kg}^{0.75}$ per $24 \mathrm{~h}$.

It was not possible to impose a statistically elegant design on these trials because we could not forecast how long an individual preparation would give useful results or how much the sheep would eat after surgery.

An attempt was made, therefore, to obtain at least six successful trials with each diet, over the widest range of food intakes in excess of maintenance that we could achieve. The first experiments were done using the dried grass and these were frustrated by blockage of catheters and because the sheep would not consume more than about $1500 \mathrm{~g}$ of these diets $/ 24 \mathrm{~h}$. Nine and ten trials were done using chopped, and pelleted, dried grass respectively.

Six trials were done using each of the lucerne diets and with the pelleted barley diet. The lucerne was apparently very palatable and the sheep would regularly eat $2250 \mathrm{~g} / 24 \mathrm{~h}$.

Each trial lasted for $24 \mathrm{~h}$. Measurements of $F, H_{t}$ and $H_{g}$ were made at about 09.00 hours, then the sheep was given its daily ration as a single meal, and subsequent measurements were made at intervals of $\mathrm{I}$ or $2 \mathrm{~h}$ until og.00 hours the next day. In the first six trials measurements were continued throughout the night, but experience and exhaustion satisfied us that the measurements at 01.00 and 03.00 hours were not necessary. Individual measurements of $F$ and $H_{t}$ were plotted graphically and average values for $F(\mathrm{ml} / \mathrm{min})$ and total $H_{t}(\mathrm{MJ} / 24 \mathrm{~h})$ were obtained by integration of the areas under the curves. Because it was not always possible to withdraw blood, measurements of $H_{g}$ could not be made as frequently or as regularly.

Successive trials were done at intervals of not less than $7 \mathrm{~d}$. The amount of food 
Vol. 34

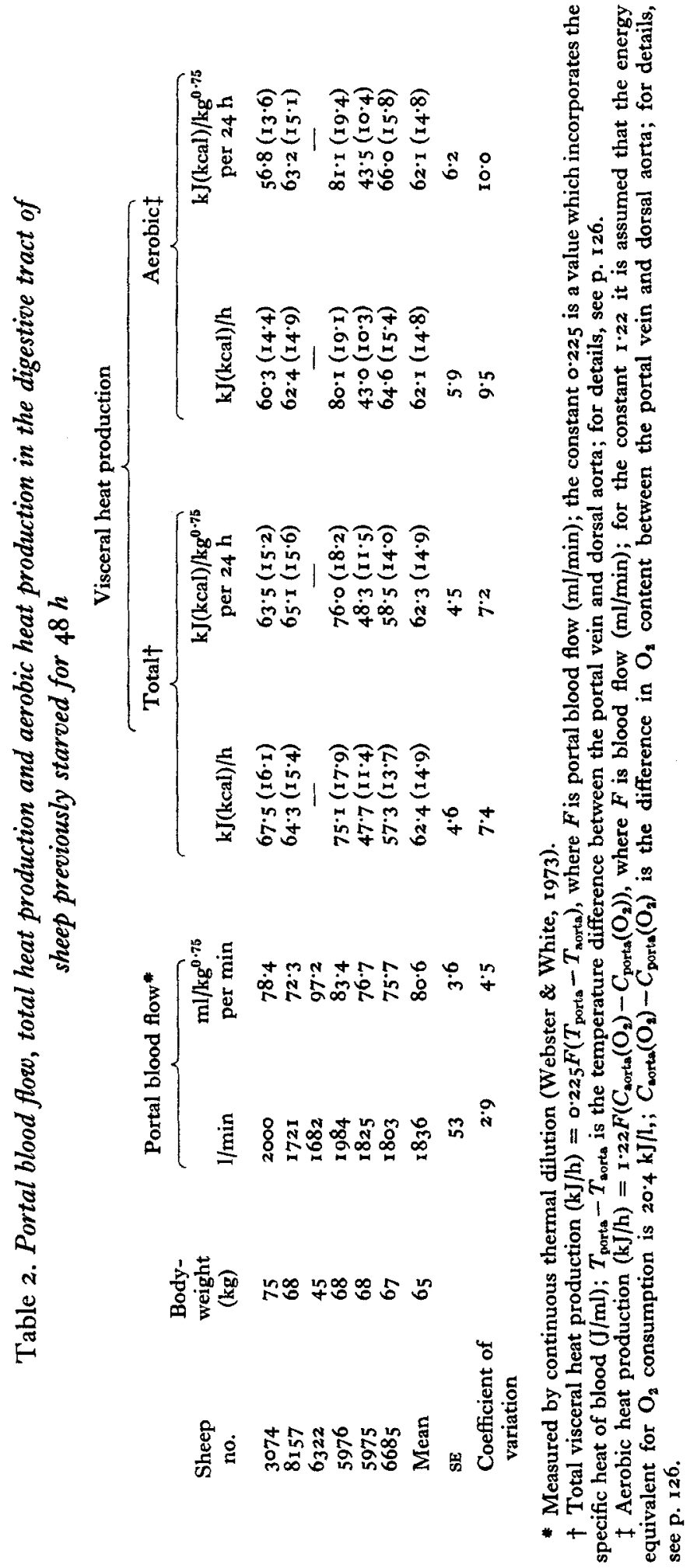




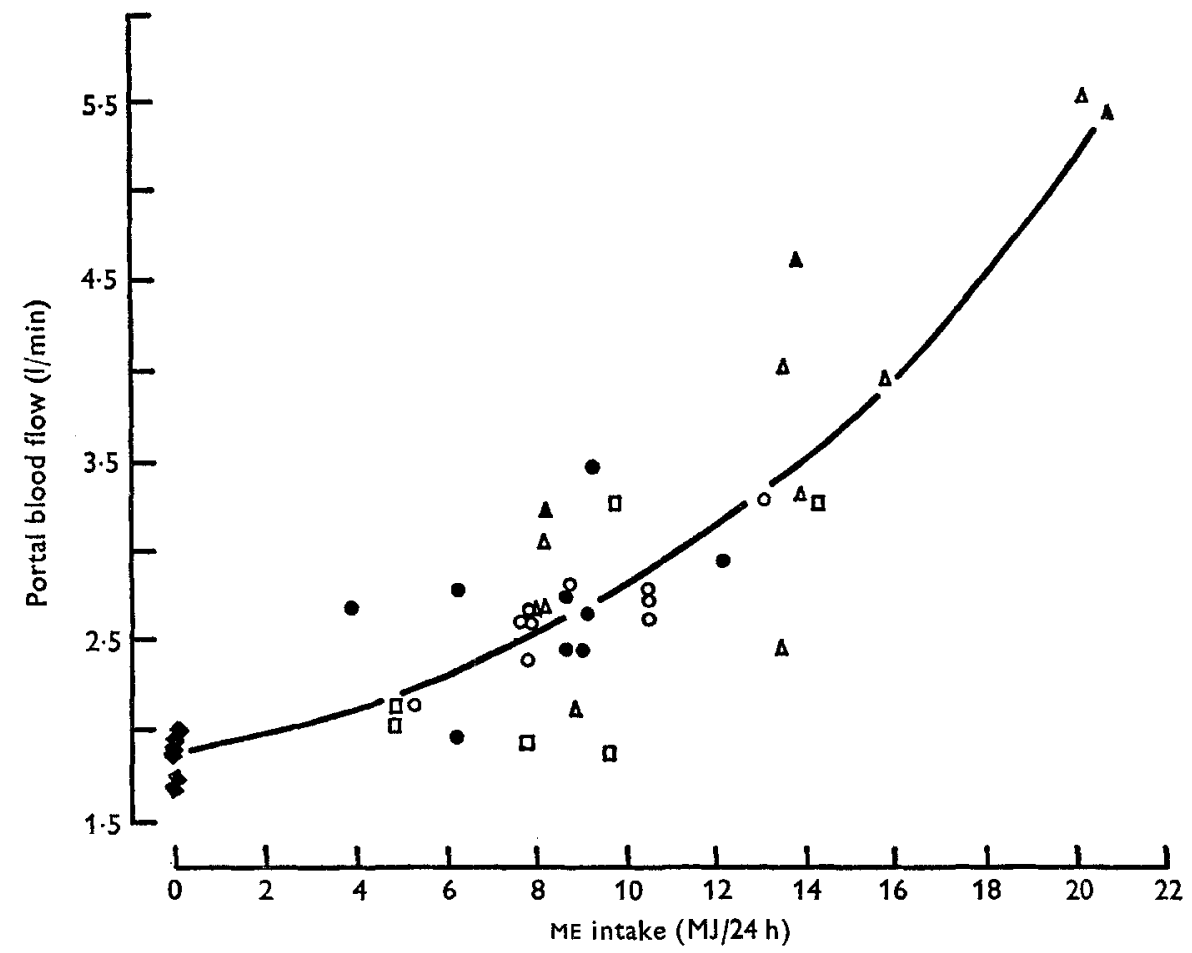

Fig. I. The relationship between portal blood flow $(1 / \mathrm{min})$ and metabolizable energy (ME) intake $(\mathrm{MJ} / 24 \mathrm{~h}$ ) for sheep given the following diets: $\Delta$, chopped, dried lucerne; $\Delta$, pelleted, dried lucerne; $\odot$, chopped, dried grass; $O$, pelleted, dried grass; $\square$, pelleted barley diet (about $800 \mathrm{~g}$ barley $/ \mathrm{kg}$ ). $\rightarrow$, Basal values.

offered to each sheep was altered immediately after each trial so that it had $7 \mathrm{~d}$ to adjust to the new level of intake. If one sheep was used to test more than one diet, about $14 \mathrm{~d}$ adaptation were allowed after the diet was changed. These adaptation periods represented a compromise between the optimal time taken for sheep to adjust to dietary changes (about 4 weeks) and the limited experimental life of the preparations (about 6 weeks).

\section{RESULTS}

\section{Post-operative history of sheep}

All the thirteen sheep used in these experiments had an uneventful recovery during the first week after surgery and would usually eat about $900 \mathrm{~g}$ of any diet $/ 24 \mathrm{~h}$, within $7 \mathrm{~d}$. Their subsequent history was more variable. The condition of two sheep suddenly deteriorated about 3 weeks after surgery. Both were found, post mortem, to have severe phlebitis in the anterior mesenteric vein. Three sheep showed intermittent fever and inappetence, beginning again about 3 weeks after surgery. These were killed painlessly by administration of sodium pentobarbitone through one of the implanted catheters, and some degree of phlebitis was found on post mortem examination in each instance. For four sheep, experiments were terminated 
Table 3. Regression analysis relating portal blood flow and total visceral heat production to metabolizable energy (ME) intake for sheep given diets of different quality and physical form

(Regressions were calculated from values given in Figs. I and 2)

Diet Equation $\quad n \quad \begin{gathered}\text { Variance ratio, } \\ \text { quadratic:residual }\end{gathered} \quad \begin{gathered}\text { Residual } \\ \text { SD }\end{gathered}$

(a) Regression for portal blood flow $(F, 1 / \mathrm{min}) v$. ME intake $(M, \mathrm{MJ} / 24 \mathrm{~h})$

All diets*, results pooled $F=+\mathrm{I} \cdot 326+0.554 e^{0.0978} M \quad 43 \quad$ I6.0 $\quad 0.42 \mathrm{I}$

(b) Regression for visceral heat production $\dagger\left(H_{t}, \mathrm{~kJ} / \mathrm{kg}^{0.75}\right.$ per $\left.24 \mathrm{~h}\right) v$. ME intake $\left(M, \mathrm{~kJ}^{\circ} \mathrm{kg}^{0.75}\right.$ per $24 \mathrm{~h}$ )

\begin{tabular}{|c|c|c|c|c|}
\hline $\begin{array}{l}\text { Dried lucerne, chopped or } \\
\text { pelleted } \ddagger\end{array}$ & $H_{t}=-57.69+\mathrm{I} \mathrm{I} 6.7 e^{0.00109} \mathrm{M}$ & $13 \S$ & $4 \cdot 40$ & $24 \cdot 68$ \\
\hline $\begin{array}{r}\text { Dried grass, chopped } \\
\text { pelleted }\end{array}$ & $\begin{array}{l}H_{t}=-35.58+93.81 e^{0.00108} M \\
H_{t}=+56.42 \pm 6.00 e^{0.00374} M\end{array}$ & $\begin{array}{l}\text { roई } \\
\operatorname{rr} \xi\end{array}$ & $\begin{array}{l}0.20 \\
3.07\end{array}$ & $\begin{array}{l}35.60 \\
22.48\end{array}$ \\
\hline arley, pelleted & $H_{t}=+56.54+4.40 e^{0.00487} M$ & $7 \S$ & $12 \cdot 2$ & 10.53 \\
\hline
\end{tabular}

* Chopped, dried grass; pelleted, dried grass; chopped, dried lucerne; pelleted, dried lucerne; a pelleted diet consisting mainly of barley (about $800 \mathrm{~g} / \mathrm{kg}$ ). For details, see Table I.

$\dagger H_{t}=0.225 F\left(T_{\text {porta }}-T_{\text {aorta }}\right)$, where $F$ is expressed on a $\mathrm{ml} / \mathrm{min}$ basis; the constant 0.22 .5 is a value which incorporates the specific heat of blood $(\mathrm{J} / \mathrm{ml}) ; T_{\text {porta }}-T_{\text {aorta }}$ is the temperature difference between the portal vein and dorsal aorta.

$\ddagger$ Regressions for chopped, dried lucerne and pelleted, dried lucerne did not differ significantly.

$\S$ Regression includes the mean value obtained for basal metabolism in the gut.

for mechanical reasons; a broken thermocouple, displaced catheter, or encapsulation of the catheter tip. The other four sheep completed their planned experimental programme.

\section{Basal metabolism in the gut}

Table 2 gives the results for each series of measurements made of $F, H_{t}$ and $H_{g}$ for the digestive tract of sheep $48-56 \mathrm{~h}$ after they had last eaten. $F$ was on average $1836 \mathrm{ml} / \mathrm{min}$ (SE 53 ). When $F$ was expressed on a $\mathrm{ml} / \mathrm{min}$ per $\mathrm{kg}$ metabolic bodyweight ( $\mathrm{kg}$ body-weight ${ }^{0.75}$ ) basis, the variation about the mean was increased. Mean values for $H_{t}$ and $H_{g}$ were remarkably similar, 62.4 (SE 4.6$)$ and 62.1 (SE 5.9$) \mathrm{kJ} / \mathrm{h}$ respectively. In this instance, expressing these values on a $\mathrm{kg}$ body-weight ${ }^{0.75}$ basis had no effect on the variability of the measurements, and values for $H_{t}$ and $H_{g}$ are hereafter considered on a $\mathrm{kJ} / \mathrm{kg}$ body-weight ${ }^{0 \cdot 75}$ per $24 \mathrm{~h}$ basis only.

The identical mean values for $H_{t}$ and $H_{y}$, obtained at a stage in the experiment when the amount of fermentation in the rumen would be negligible, provided confirmation of the absence of any serious systematic error in the equations used to calculate $H_{t}$ and $H_{g}$, and suggested that differences between $H_{t}$ and $H_{g}$ for the fed animal could reliably be ascribed to the heat of fermentation for the gut $\left(H_{f}\right)$.

\section{Responses to food intake}

F (portal blood flow). All mean values obtained for $F(1 / \mathrm{min})$ for periods of $24 \mathrm{~h}$ are shown in Fig. I. There was no apparent significant difference between values for $F$ that could be attributed to the quality of the different diets, but $F$ was clearly 


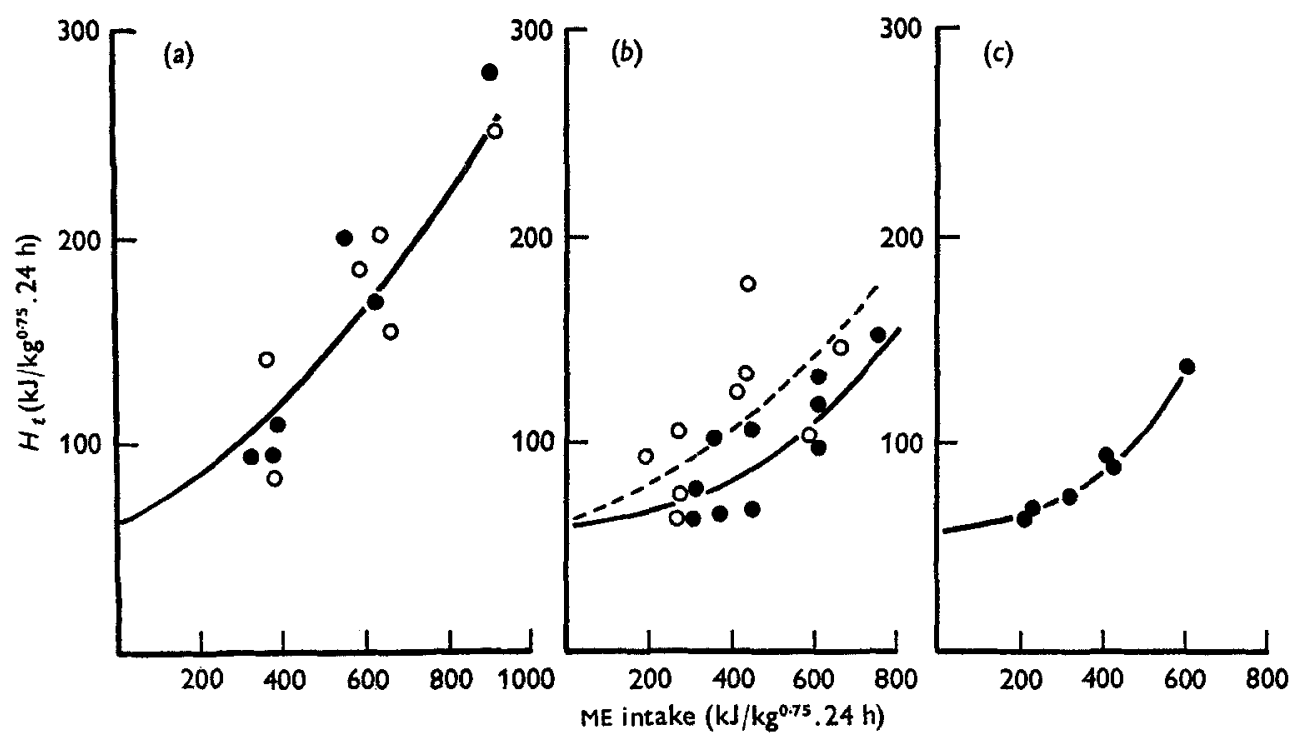

Fig. 2. The relationship between the total visceral heat production $\left(H_{t}, \mathrm{~kJ} / \mathrm{kg}^{0.75}\right.$ per $\left.24 \mathrm{~h}\right)$ and metabolizable energy (ME) intake ( $\mathrm{kJ} / \mathrm{kg}^{0 \cdot 75}$ per $24 \mathrm{~h}$ ) for sheep given the following diets: $(a)$ dried lucerne, chopped $(O)$ or pelleted $(O) ;(b)$ dried grass, chopped $(O)$ or pelleted $(O) ;(c)$ pelleted barley diet (about $800 \mathrm{~g}$ barley $/ \mathrm{kg})(0) . H_{t}=0.225 F\left(T_{\text {porta }}-T_{\text {aorta }}\right.$ ), where $F$ is the portal blood flow $(\mathrm{ml} / \mathrm{min})$; the constant 0.225 is a value which incorporates the specific heat of blood $(\mathrm{J} / \mathrm{ml}) ;\left(T_{\text {porta }}-T_{\text {aorta }}\right)$ is the temperature difference between the portal vein and dorsal aorta.

related to the quantity of material eaten. The relationship between $F$ and ME intake was markedly curvilinear; the variance ratio, quadratic: residual was $16.0(P<0.01$, Table 3). The residual standard deviation for the quadratic equation was $0.425 \mathrm{l} / \mathrm{min}$, which was reduced to $0.4211 / \mathrm{min}$ by using the exponential equation given in Table 3 and illustrated in Fig. I.

$\mathrm{H}_{\mathrm{t}}$ (total heat production in the gut). The relationship between $H_{t}$ and ME intake is shown in Fig. 2; values for $H_{t}$ at zero food intake were included in deriving the curves. There was no apparent difference between the chopped and pelleted driedlucerne diets. The relationship was better described by a quadratic than by a linear equation ( $0.1>P>0.05)$ and the residual standard deviation was least when the exponential expression given in Table 3 was used. When the sheep were given pelleted, dried grass, the relationship between $H_{t}$ and ME intake was again best described by the exponential equation given in Table 3 and shown in Fig. 2. The results obtained with chopped, dried grass were extremely variable and for this reason quadratic or exponential expressions do not describe the results more adequately than linear regression would describe them; however, the results in Table 3 are given in exponential form to correspond with the other diets.

The relationship between $H_{t}$ and ME intake for the barley diet was very precise and significantly curvilinear $(P<0.05)$ although the number of points on the graph was low. At about the maintenance level of intake (400 kJ ME/ $/ \mathrm{kg}^{0 \cdot 75}$ per $24 \mathrm{~h}$ ), the predicted $H_{t}$ value for the lucerne diets was $116 \mathrm{~kJ} / \mathrm{kg}^{0.75}$ per $24 \mathrm{~h}$ and for both 
Table 4. Aerobic and anaerobic metabolic rate in the digestive tract for individual sheep eating diets of different quality and physical form

\begin{tabular}{|c|c|c|c|c|c|c|}
\hline \multirow[b]{3}{*}{ Diet* } & \multicolumn{5}{|c|}{$\begin{array}{c}\begin{array}{c}\text { Energy exchanges in gut }\left(\mathrm{kJ} / \mathrm{kg}^{0 \cdot 75}\right. \\
\text { per } 24 \mathrm{~h})\end{array} \\
.\end{array}$} & \multirow{3}{*}{$\begin{array}{c}\text { Anaerobic heat: } \\
\text { DE intake } \\
(\mathrm{kJ} / \mathrm{MJ})\end{array}$} \\
\hline & \multirow{2}{*}{$\begin{array}{l}\text { Physical } \\
\text { form of } \\
\text { diet }\end{array}$} & \multirow{2}{*}{$\begin{array}{c}\mathrm{DE} \\
\text { intake }\end{array}$} & \multicolumn{3}{|c|}{ Heat production } & \\
\hline & & & Totalt & Aerobict & Anaerobic§ & \\
\hline \multirow[t]{2}{*}{ Dried grass } & Chopped & $\begin{array}{l}533 \\
35 \mathrm{I}\end{array}$ & $\begin{array}{l}128 \\
96 \cdot 2\end{array}$ & $\begin{array}{l}80 \cdot 2 \\
64 \cdot 3\end{array}$ & $\begin{array}{l}47 \cdot 8 \\
3 I \cdot 9\end{array}$ & $\begin{array}{l}89 \\
91\end{array}$ \\
\hline & Pelleted & $\begin{array}{l}376 \\
372\end{array}$ & $\begin{array}{l}96 \cdot 3 \\
96 \cdot 5\end{array}$ & $\begin{array}{l}63 \cdot 5 \\
62 \cdot 0\end{array}$ & $\begin{array}{l}32 \cdot 8 \\
14 \cdot 5\end{array}$ & $\begin{array}{l}87 \\
38\end{array}$ \\
\hline Mean (SE) & & & & & & $76(13 \cdot 2)$ \\
\hline \multicolumn{2}{|c|}{ Dried lucerne Chopped } & $\begin{array}{l}787 \\
45^{6}\end{array}$ & $\begin{array}{l}\text { I } 54 \\
82 \cdot 8\end{array}$ & $\begin{array}{l}95 \cdot 3 \\
65 \cdot 7\end{array}$ & $\begin{array}{l}58 \cdot 7 \\
17 \cdot 7\end{array}$ & $\begin{array}{l}74 \\
37\end{array}$ \\
\hline & Pelleted & $\begin{array}{l}463 \\
456 \\
436\end{array}$ & $\begin{array}{l}106 \\
95.0 \\
91.4\end{array}$ & $\begin{array}{l}54^{\cdot 2} \\
75^{\circ} 5 \\
75^{\cdot 2}\end{array}$ & $\begin{array}{l}5 I \cdot 8 \\
19 \cdot 5 \\
16 \cdot 2\end{array}$ & $\begin{array}{r}\text { II I } \\
43 \\
37\end{array}$ \\
\hline Mean (SE) & & & & & & $60(19.1)$ \\
\hline Barley & Pelleted & $\begin{array}{l}443 \\
364 \\
443\end{array}$ & $\begin{array}{l}93 \cdot 2 \\
74 \cdot 6 \\
91 \cdot 5\end{array}$ & $\begin{array}{l}85 \cdot 3 \\
66 \cdot 2 \\
80 \cdot 7\end{array}$ & $\begin{array}{r}7 \cdot 9 \\
8 \cdot 4 \\
10 \cdot 8\end{array}$ & $\begin{array}{l}18 \\
23 \\
24\end{array}$ \\
\hline $\begin{array}{l}\text { Mean (SE) } \\
\text {, digestible } \\
\text { For details, } \\
\text { Total heat } \\
\text { tant } 0.225 \text { is } \\
\text { perature diffe } \\
\text { Aerobic he } \\
\text { min); for the } \\
\left(\mathrm{O}_{2}\right)-C_{\text {porta }} \\
\text { Total - aero }\end{array}$ & $\begin{array}{l}\text { Table } \mathrm{I} \text {. } \\
\text { duction }= \\
\text { value wh } \\
\text { ace betwe } \\
\text { productio } \\
\text { nstant } \mathrm{I} 2 \\
\text { ) is the d }\end{array}$ & $\begin{array}{l}25 F(2 \\
\text { incorp } \\
\text { he por } \\
1 \cdot 22 \\
\text { s assu } \\
\text { ence i }\end{array}$ & $\begin{array}{l}\left.\Gamma_{\text {aorta }}\right) \text {, } \\
\text { the sp } \\
\text { and d } \\
\left(\mathrm{O}_{2}\right)- \\
\text { the e }\end{array}$ & $\begin{array}{l}\mathrm{e} F \text { is th } \\
\text { heat of } \\
\text { aorta. } \\
\left(\mathrm{O}_{2}\right) \text { ), wh } \\
\text { equivale }\end{array}$ & $\begin{array}{l}\text { irtal blood } \\
\mathrm{d}(\mathrm{J} / \mathrm{ml}) \text {; } \\
\mathrm{F} \text { is the } \\
\mathrm{O}_{2} \text { consu }\end{array}$ & $\begin{array}{l}\mathrm{w}(\mathrm{ml} / \mathrm{min}) \text {; the } \\
\text { srta }-T_{\text {aorta }} \text { is the } \\
\text { ortal blood flow } \\
\text { ption is } 20.4 \mathrm{~kJ} / 1 \text {; } \\
\text { sal aorta. }\end{array}$ \\
\hline
\end{tabular}

the barley and pelleted, dried-grass diets it was $80 \mathrm{~kJ} / \mathrm{kg}^{0.75}$ per $24 \mathrm{~h}$; these two predicted values differed significantly $(P<0.05)$.

$\mathrm{H}_{\mathrm{g}}$ (aerobic metabolism) and $\mathrm{H}_{\mathrm{f}}$ (fermentation heat). As indicated earlier, on many occasions catheters would allow infusion but not withdrawal of blood, therefore $F$ and $H_{t}$ could be measured but not $H_{g}$. Only for twelve experiments could blood be withdrawn consistently enough to obtain reliable estimates for $H_{g}$. The results for these trials are given in Table 4 ; they indicate that $H_{t}$ was greater than $H_{g}$ in all instances. The difference between $H_{t}$ and $H_{y}$, the anaerobic heat production, which is principally attributable to $H_{f}$, is expressed on a digestible energy (DE) intake basis $(\mathrm{kJ} / \mathrm{MJ} \mathrm{DE})$, in Table 4 . The values for dried grass, dried lucerne and barley were 76,60 and $22 \mathrm{~kJ} / \mathrm{MJ}$ DE respectively. The value for barley was significantly $(P<0.05)$ less than the mean value for the other two diets. 


\section{Validity of method}

The use of cool saline as a marker for the measurement of blood flow and the estimation of $H_{t}$ from $T_{\text {porta }}-T_{\text {aorta }}$ both depend on the assumption that effectively all the heat produced in the gut, or 'coolth' introduced into the veins, is convected out into the portal vein by the mesenteric circulation. In a previous report (Webster \& White, I973) we indicated that our estimate of $H_{t}$ from equation I (p. I26) precisely measured the increase in heat production for the gut of sheep, when an immersion heater, inserted into the rumen through a fistula, was operated at $29.6 \mathrm{~W}(106 \mathrm{~kJ} / \mathrm{h})$. While this finding was reassuring, the possibility remained that transfer of heat across the walls of blood vessels could have resulted in an over-estimation of blood flow rate from measurements of thermal dilution, and an underestimate of the heat gain per unit volume of blood from measurements of $T_{\text {porta }}-T_{\text {aorta }}$; the two errors would cancel one another out in the final estimation of $H_{t}$.

In the present experiments, however, there was excellent agreement between our estimates for $H_{t}$ and $H_{g}$ for the fasting sheep, the latter measurements being derived from $C_{\text {aorta }}\left(\mathrm{O}_{2}\right)-C_{\text {porta }}\left(\mathrm{O}_{2}\right)$. Since the estimation of $H_{g}$ is not open to the possible criticism made previously for $H_{t}$ estimation, this agreement provides evidence that our approach measures $F, H_{t}$ and $H_{g}$ without any serious systematic error.

Measurements of $H_{g}$ were less reliable than those of $H_{t}$, partly because problems of blocked catheters reduced the number of samples that we could obtain, and partly because measurements of $C\left(\mathrm{O}_{2}\right)$ were made on single samples of blood, whereas $T_{\text {porta }}-T_{\text {aorta }}$ were mean values for a $1_{5} \mathrm{~min}$ measurement period. For this reason our estimates for anaerobic metabolism from $H_{t}-H_{g}$ can only be approximate; good enough to draw conclusions about the contribution of $H_{f}$ to the total heat increment of feeding, but probably not sensitive enough to reveal small differences in $H_{f}$ due, for example, to manipulation of the patterns of rumen fermentation.

\section{Regulation of $\mathrm{F}$ (portal blood flow)}

There were no significant differences between diets for $F$, that could not be attributed to the quantity of food eaten. The variation between diets for the relationship between $F$ and ME intake was considerable (residual SD $0.421 / \mathrm{min}$ ) but there was no indication from Fig. I that significant differences between diets might have been achieved by more prolonged studies. Differences in $F$ attributable to the quality of the diets tested are probably not important.

Bensadoun, Paladines \& Reid (1962), Katz \& Bergman (1969), and Webster \& White (1973) have reported that, for the sheep, $F$ increases after a meal has been eaten, and the time-course for changes in $F$ during a $24 \mathrm{~h}$ period, for sheep eating different quantities of food was described by Webster (1974). There has not yet, however, been a systematic study of the physiological mechanisms involved in this increase.

A comprehensive study has been made of factors influencing blood flow in the 
major stomach arteries (Sellers, Stevens, Dobson \& McLeod, r964; Sellers, 1965). In these experiments feeding increased blood flow in the right ruminal artery, but not in the caudal mesenteric or hypogastric arteries. Insufflation of the rumen with $\mathrm{CO}_{2}$ increased blood flow in the rumen artery by about $20-50 \%$. Infusions of acetate, propionate or butyrate increased blood flow by, very approximately, IO, 50 and more than $100 \%$ respectively, although there were limits to the increase that could be induced by both propionate and butyrate, presumably occurring when the blood vessels were fully dilated. Weekes \& Webster (1975, and unpublished results) found that portal venous flow is increased by propionate and butyrate infusions to an extent comparable to that found in the right ruminal artery by Sellers (1965). Physiologically normal variations in the entry of protein nitrogen, amino acids or urea into the rumen or abomasum do not however appear to have any marked effect on $F$ (M. Chalmers, F. White, \& A. J. F. Webster, unpublished results).

Variations in blood flow through the tissues of the digestive tract probably do not influence the absorption of VFA or urea, but do determine the movement of some compounds, for example, tritiated water and ethanol (Dobson, Sellers \& Thorlacius, 1971). The extent to which variations in blood flow in the mesenteric circulation affect the absorption of nutrients from the digestive tract, and the relative times at which they become available to the tissues for metabolism, remains to be studied.

\section{$\mathrm{H}_{\mathrm{f}}$ (fermentation heat)}

The values obtained for the anaerobic metabolism of the digestive tract $\left(H_{t}-H_{g}\right)$ can, with the qualifications given previously, be considered to represent $H_{f}$. Weekes $\&$ Webster (1975) showed that anaerobic metabolism by the tissues of the portaldrained viscera produced lactate at a rate of about $8.6 \mathrm{mmol} / \mathrm{kg}^{0.75}$ per $24 \mathrm{~h}$. The enthalpy change associated with this rate of lactate production would be only about $0.4 \mathrm{~kJ} / \mathrm{kg}^{0.75}$ per $24 \mathrm{~h}$.

We know of no previous in vivo estimates of $H_{f}$. Marston (1948) and Houpt ( 1968 ) have measured $H_{f}$ in vitro, using rumen contents from sheep and cattle respectively, and both workers obtained values of $60-80 \mathrm{~kJ} / \mathrm{MJ}$ DE. Hungate (1966) reported that the theoretical amount of heat produced from the fermentation of hexose sugars to VFA is $65 \mathrm{~kJ} / \mathrm{MJ}$ hexose fermented, independent of the molar proportions of VFA produced. The ratio of energy loss as methane: $H_{f}$ is $2 \cdot 8: 1$ when fermentation yields acetate, propionate and butyrate in an approximate molar ratio of $2: 1: 1$.

Table 5 gives the amounts of DE lost as $H_{f}$ and as methane in the present experiments. The values for methane production were obtained during the determination of the ME content of the diets using closed-circuit respiration chambers. The results in Table 5 suggested that our estimates for $H_{f}$ for the grass and lucerne diets agreed well with stoichiometric calculations if it is assumed that nearly all the DE was fermented. The low value for $H_{f}$ for the barley diet was associated with a correspondingly low value for methane production, which suggested that a considerable amount of it escaped fermentation. The ratio of methane energy loss: $H_{f}$ was lower 


\section{r36 A. J. F. Webster, P. O. Osuji, F. White and J. F. Ingram 1975 \\ Table 5. Losses of digestible energy (DE) as methane and as heat during fermentation for three diets fed to sheep}

(Results for methane energy are mean values for three sheep, those for fermentation heat are means from Table 4)

\begin{tabular}{|c|c|c|c|}
\hline \multirow[b]{2}{*}{ Diet* } & \multicolumn{2}{|c|}{ Loss of $\mathrm{DE}(\mathrm{kJ} / \mathrm{MJ})$} & \multirow{2}{*}{$\begin{array}{c}\text { Energy ratio, } \\
\text { methane:fermentation } \\
\text { heat }\end{array}$} \\
\hline & $\begin{array}{l}\text { Methane } \\
\text { energy† }\end{array}$ & $\begin{array}{c}\text { Fermentation } \\
\text { heat } f\end{array}$ & \\
\hline $\begin{array}{l}\text { Dried grass, chopped } \\
\text { or pelleted }\end{array}$ & 116 & 76 & $1 \cdot 52$ \\
\hline $\begin{array}{l}\text { Dried lucerne, chopped } \\
\text { or pelleted }\end{array}$ & 106 & 60 & $1 \cdot 76$ \\
\hline Barley, pelleted & 49 & 22 & $2 \cdot 22$ \\
\hline
\end{tabular}

than that predicted by Hungate (1966). However, Hungate himself failed to obtain good agreement between measured and predicted fermentation balance in the rumen, probably, for the most part, because the rumen does not exclusively ferment hexose sugars. The best conclusion, therefore, that can be drawn from the present experiments is that our rather imprecise in vivo estimates for $H_{f}$ confirm reasonably well Hungate's predictions that the energy loss as heat during fermentation in the rumen is about $60-70 \mathrm{~kJ} / \mathrm{MJ}$ fermented substrate.

\section{$\mathrm{H}_{\mathrm{g}}$ (aerobic metabolism in the gut)}

Basal metabolic rate in the tissues of the gut was about $62 \mathrm{~kJ} / \mathrm{kg}^{0.75}$ per $24 \mathrm{~h}$. The best estimate of fasting metabolism for adult wether sheep based on several hundred calorimetric measurements is about $275 \mathrm{~kJ} / \mathrm{kg}^{0.75}$ per $24 \mathrm{~h}$. For the fasted animal, therefore, the portal-drained viscera contributed about $23 \%$ of total heat production. The increase in $H_{g}$ in the gut with increasing food intake between fasting and about maintenance was, on average, about $65 \mathrm{~kJ} / \mathrm{MJ}$ gross energy (GE) eaten (Table 6). The increase was less with the pelleted, dried grass and pelleted barley than with the other diets. Between maintenance and twice maintenance levels of intake the increase in $H_{g}$ in the gut was about $120 \mathrm{~kJ} / \mathrm{MJ}$ GE. At twice maintenance the contribution of the portal-drained viscera to total heat production had increased to about $33 \%$.

The physiological mechanisms responsible for this large increase in metabolic rate in the tissues of the gut wall remain to be explained. Zuntz (1906) suggested that a large part of the heat increment of feeding for ruminants could be attributed to the 'work of digestion', the motor and secretory processes accompanying the 
Table 6. Approximate values for utilization of gross energy (GE) for maintenance and production, for diets of different quality and physical form fed to sheep

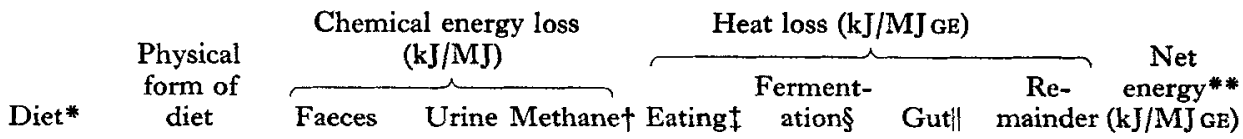

(a) For levels of intake below maintenance ๆ

\begin{tabular}{llrrrrrrrr} 
Dried lucerne Chopped & 290 & 67 & 67 & 12 & 34 & 86 & 39 & 405 \\
\multirow{5}{*}{ Dried grass } & Pelleted & 315 & 62 & 78 & 2 & 33 & 84 & 47 & 381 \\
& Chopped & 320 & 48 & 78 & 12 & 51 & 66 & 72 & 387 \\
Barley & Pelleted & 340 & 46 & 76 & 2 & 49 & 28 & 72 & 387 \\
& Pelleted & 250 & 62 & 53 & 2 & 16 & 53 & 115 & 449
\end{tabular}

(b) For levels of intake above maintenance

$\begin{array}{llrrrrrrrr}\text { Dried lucerne Chopped } & 332 & 61 & 56 & 12 & 33 & 134 & 200 & 172 \\ \text { Pelleted } & 334 & 50 & 64 & 2 & 33 & 135 & 140 & 244 \\ \text { Dried grass } & \text { Chopped } & 390 & 43 & 70 & 11 & 46 & 98 & 159 & 183 \\ & \text { Pelleted } & 430 & 40 & 65 & 2 & 43 & 78 & 136 & 206 \\ \text { Barley } & \text { Pelleted } & 210 & 36 & 34 & 2 & 17 & 160 & 196 & 345\end{array}$

* For details, see Table $r$.

$\uparrow$ Values obtained during the measurement of metabolizable energy (ME) contents of the diets, using closed-circuit respiration chambers, by the Calorimetry section of The Rowett Institute, Aberdeen.

I From Osuji, Gordon \& Webster (1975).

$\S$ Total visceral heat production - aerobic heat production, where total visceral heat production $=0.225 F\left(T_{\text {porta }}-T_{\text {aorta }}\right)$ ( $F$ is portal blood flow $(\mathrm{ml} / \mathrm{min})$; the constant is a value which incorporates the specific heat of blood $(\mathrm{J} / \mathrm{ml}) ; T_{\text {porta }}-T_{\text {a orta }}$ is the temperature difference between the portal vein and dorsal aorta).

$\|$ Aerobic heat production $={ }_{1} \cdot 22 F\left(C_{\text {aorta }}\left(\mathrm{O}_{2}\right)-C_{\text {porta }}\left(\mathrm{O}_{2}\right)\right)$, where $F$ is the portal blood flow $(\mathrm{ml} / \mathrm{min})$; for the constant $\mathrm{I} \cdot 22$ it is assumed that the energy equivalent for $\mathrm{O}_{2}$ consumption is $20.4 \mathrm{~kJ} / 1$; $C_{\text {aorta }}\left(\mathrm{O}_{2}\right)-C_{\text {porta }}\left(\mathrm{O}_{2}\right)$ is the difference in $\mathrm{O}_{2}$ content between the portal vein and dorsal aorta.

II Maintenance level of intake for ME taken as $400 \mathrm{~kJ} / \mathrm{kg}^{0.75}$ per $24 \mathrm{~h}$.

** Derived from the net availability of $\mathrm{ME}$, below and above maintenance levels of intake, see Table $\mathbf{~}$.

movement of a stated volume of food along the gut. 'This hypothesis would explain differences in the efficiency of utilization of the ME content of foods attributable to their fibre content, but not to their molar yield of VFA (Armstrong \& Blaxter, 1957 $b$; Annison \& Armstrong, 1970). The relatively small increase in $H_{t}$ when pelleted, dried grass or barley were eaten below maintenance levels of intake suggested that the 'work of digestion' for these concentrated diets was relatively small, although the results obtained when pelleted, dried lucerne was eaten do not confirm this. Moreover, a hypothesis which attributes the metabolic rate of the gut simply to the bulk of material in it cannot explain the curvilinearity of response of $H_{g}$ to increasing ME intake. Thus while there may be a small component of $H_{g}$ that can be attributed to the bulkiness of the diet, much of the heat production in the gut is probably derived from metabolic reactions that are not directly linked to the process of digestion. Weekes (1973) has shown that the rate of cell division and cell growth for the rumen mucosa are closely and positively correlated with food intake $(r 0.91)$. This suggests that the energy cost of rapid cell turnover is probably 
a large contributor to the metabolic rate of the gut, particularly when food intake is high.

\section{Analysis of the heat increment of feeding}

Contributors to the heat increment of feeding include the energy costs of eating and rumination, $H_{f}$, and $H_{g}$ in the gut. The remainder must be associated with the liver and other tissues outside the gut. The main losses of energy from food as it is eaten and processed by the gut and tissues into net energy for maintenance and fattening are shown in Table 6 . Values for the energy costs of eating and rumination are from Osuji, Gordon \& Webster (1975). The net energy values are derived using the values for net availability of $\mathrm{ME}$, below and above maintenance levels of intake, given in Table $\mathrm{I}$. As these derived values are subject to at least as much variation as those obtained in the present experiments for $H_{f}$ and $H_{g}$ the values given in Table 6 are only first approximations. However, certain points can be made with some assurance. The energy cost of eating these dried and processed diets accounted for only about $\mathrm{I} \%$ of GE. Fermentation accounted for, an average, less than $4 \%$. Below maintenance levels of intake, the increase that occurred in heat production both in the gut and other tissues (remainder) was about $4-10 \%$ of GE intake. Between maintenance and twice maintenance levels of intake the increment in heat production in the gut and other body tissues increased sharply to about $12 \%$ and $16 \%$ of GE respectively. The remaining tissues therefore contributed at least as much as the tissues of the gut to this increase in heat production. This is further proof that the decline in efficiency with which ME surplus to maintenance requirements is retained in the body as foods become more fibrous cannot be attributed to any extent to the physical work of processing the food in the gut, but must be due, as suggested by Armstrong \& Blaxter (1957 $a, b$ ), mainly to the nature of the substrates made available by digestion and the metabolic reactions for which they are used.

The authors acknowledge the skilled contribution of Mr L. E. Vowles and $\mathrm{Mr}$ G. Wenham during the surgical preparation of these animals. Thanks are also due to Rhona McKenzie for statistical assistance, and to Mr F. W. Wainman and Mr J. S. Smith for providing information about the nutritive value of the diets used.

\section{REFERENCES}

Annison, E. F. \& Armstrong, D. G. (1970). In Physiology of Digestion and Metabolism in the Ruminant, p. 422 [A. T. Phillipson, editor]. London: Butterworths.

Armstrong, D. G. \& Blaxter, K. L. (1957a). Br. F. Nutr. I1, 247.

Armstrong, D. G. \& Blaxter, K. L. (1957b). Br. F. Nutr. II, 413.

Bensadoun, A., Paladines, O. L. \& Reid, J. T. (I962). F. Dairy Sci. 45, 1203.

Blaxter, K. L. (1962). The Energy Metabolism of Ruminants. London: Hutchinson.

Dobson, A., Sellers, A. F. \& Thorlacius, S. O. (1971). Am. F. Physiol. 220, 1337.

Houpt, T. R. (1968). Am. F. vet. Res. 29, 4I I.

Hungate, R. E. (1966). The Rumen and its Microbes. London: Academic Press.

Katz, M. L. \& Bergman, E. N. (1969). Am. Y. Physiol. 216, 946.

Marston, H. R. (1948). Biochem. F. 42, 564.

Osuji, P. O., Gordon, J. G. \& Webster, A. J. F. (1975). Br. F. Nutr. 34, 59. 
Sellers, A. F. (1965). In Physiology of Digestion in the Ruminant, p. I7I [R. W. Dougherty, editor]. London: Butterworths.

Sellers, A. F., Stevens, C. E., Dobson, A. \& McLeod, F. D. (1964). Am. Y. Physiol. 207, 371.

Wainman, F. W., Blaxter, K. L. \& Smith, J. S. (1972). F. agric. Sci., Camb. 78, 441.

Webster, A. J. F. (1974). Proc. Nutr. Soc. 33, I 55 .

Webster, A. J. F., Brockway, J. M. \& Smith, J. S. (1974). Anim. Prod. r9, 127.

Webster, A. J. F., Osuji, P. O., White, F. \& Ingram, J. F. (r974). Publs Eur. Ass. Anim. Prod. no. 14, p. 55 .

Webster, A. J. F. \& White, F. (1973). Br. F. Nutr. 29, 279.

Weekes, T. E. C. (1973). Observations on the metabolic role of the rumen epithelium. PhD Thesis, University of Aberdeen.

Weekes, T. E. C. \& Webster, A. J. F. (1975). Br. F. Nutr. 33, 425.

Zuntz, N. (1906). Naturw. Rdsch., Braunschw. 21, no. 38. 